\title{
Network Theory in Autoimmunity
}

\author{
IN VITRO SUPPRESSION OF SERUM ANTI-DNA ANTIBODY
}

BINDING TO DNA BY ANTI-IDIOTYPIC

ANTIBODY IN SYSTEMIC LUPUS ERYTHEMATOSUS

\author{
Nabih I. Abdou, Helen Wall, Herbert B. Lindsley, John F. Halsey, and Tsuneo \\ Suzuki, Department of Medicine, Division of Allergy, Clinical Immunology and \\ Rheumatology, and Departments of Biochemistry and Microbiology, University \\ of Kansas Medical Center, Kansas City, Kansas 66103; Veterans Administration \\ Hospital, Kansas City, Missouri 64128
}

A B S T R A C T Regulation of serum anti-DNA antibody in systemic lupus erythematosus (SLE) by an antiidiotypic antibody was evaluated. Various sera from SLE patients in active and inactive states of their disease, as well as sera from normal individuals, were first completely depleted of anti-DNA and of DNA by affinity chromatography. The suppressive capacity of equimolar concentrations of the various depleted sera (blocking sera) on target lupus sera were determined. The target sera were from lupus patients with known DNA-binding capacity. Blocking sera from inactive SLE suppressed the binding of autologous anti-DNA antibody to $\left[{ }^{3} \mathrm{H}\right] \mathrm{DNA}(n=19, P<0.01)$. Blocking sera from active SLE ( $n=19$ ), as well as human serum albumin, did not suppress. Sera from normal donors who had no contact with lupus patients or with lupus sera did not suppress $(n=14, P>0.5)$, whereas those from normal donors who had contact with lupus patients or sera did suppress the binding $(n=5, P<0.02)$. The anti-anti-DNA antibody suppressive activity in the inactive lupus serum was shown to be localized within the $F\left(a b^{\prime}\right)_{2}$ portion of immunoglobulin (Ig)G and could not be removed upon adsorption by normal human gammaglobulin. Furthermore, immune complexes could be detected by a Clq binding assay when the inactive lupus blocking sera were incubated with the anti-DNA antibody containing target sera. The

This work appeared in abstract form. (1980. J. Allergy Clin. Immunol. 65: 221; Clin. Res. 28: 338A.)

Address all correspondence to Dr. N. I. Abdou, University of Kansas Medical Center, Division of Allergy, Clinical Immunology and Rheumatology, Room 416C, Kansas City, Kans. 66103.

Received for publication 26 October 1980 and in revised form 24 November 1980. specificity of the suppressive serum factor was shown by its inability to block the binding of tetanus toxoid to antitetanus antibody and its ability to block the binding of DNA to $F\left(a b^{\prime}\right)_{2}$ fragments of active lupus IgG.

Regulation of serum anti-DNA antibody levels by anti-antibodies could induce and maintain disease remission in lupus patients and prevent disease expression in normals.

\section{INTRODUCTION}

Regulation of antibody synthesis and of lymphocytes involved in the immune response has been proposed by Jerne (1) to be controlled by a network of antibodies and lymphocytes. Antiidiotypic antibodies directed against cell-surface receptors or secreted idiotypic molecules have been shown to be important elements in transplantation tolerance or the specific suppression of an antibody response $(2,3)$. Antiidiotypic antibodies that recognize and regulate the expression of idiotypic determinants on the cell surface could theoretically play a key role in the induction of self-tolerance and the prevention of autoimmunity. Abnormalities in the idiotype antiidiotype system could therefore lead to expression or expansion of autoreactive cell clones (4-6).

Self-tolerance is also dependent on suppressor cells (7). Suppressor cell dysfunction could in part be responsible for autoantibody production in systemic lupus erythematosus $(\mathrm{SLE})^{1}(8,9)$. In fact, there appears to be a close interplay between suppressor cells and the idiotypic network in the regulation of the immune response (10-12).

In this study we have tested an extension of the net-

${ }^{1}$ Abbreviation used in this paper: SLE, systemic lupus erythematosus. 
work theory (1) with respect to modulation of the expression of autoantibody activity by presumed antiidiotypic factors. We have demonstrated the presence of autoantiidiotypic antibody in sera of inactive SLE patients. In normal individuals who have had contact with lupus material, we found a cross-reacting antiidiotypic antibody against double-stranded DNA antibody. The effector activity is present in the $\mathrm{F}\left(\mathrm{ab}^{\prime}\right)_{2}$ portion of immunoglobulin (Ig)G from sera of inactive SLE patients; it binds more avidly to autologous anti-DNA antibody than to antibody from unrelated donors. The blocking antibody could not inhibit an unrelated antigen-antibody reaction and could not be detected in sera of active SLE patients or in sera of normal individuals not exposed to lupus sera.

\section{METHODS}

Patients and controls. 19 patients who satisfied the American Rheumatism Association preliminary diagnostic criteria for SLE (13) were studied. 19 normal healthy individuals without personal or family history suggestive of an autoimmune state and with normal levels $(<6.4 \%$ binding) of serum antiDNA antibody were used as controls. 5 of the 19 normal individuals had contact with lupus patients and sera for varying periods of time $(0.5-16 \mathrm{yr})$, and the other 14 normals had no contact with lupus material. The study was approved by the institution's human subjects committee and informed consents were obtained from all of the subjects who entered the study. All patients were studied twice, when their disease was active and again during clinical remission. Patients were considered to have active disease if organ-specific clinical symptoms plus at least two of the following laboratory criteria were present: $(a)$ erythrocyte sedimentation rate $>25 \mathrm{~mm} / \mathrm{h}$; (b) total hemolytic complement $\mathrm{CH}_{50}<120 \mathrm{U}$; (c) DNA antibodies $>14 \%$ binding. Patients were considered to have inactive disease if no organ-specific clinical symptoms or signs could be elicited and if the laboratory criteria-erythrocyte sedimentation rate, $\mathrm{CH}_{50}$, DNA antibodies-were within the normal range. None of the patients was on cytotoxic drugs. Prednisone dosage received by patients during active disease ranged from 5 to $6 \mathrm{mg} / \mathrm{d}$ (mean, $32.5 \mathrm{mg}$ ), and during inactive disease, from 0 to $40 \mathrm{mg} / \mathrm{d}$ (mean, $25 \mathrm{mg} / \mathrm{d}$ ).

Serum complement determination $\left(\mathrm{CH}_{50}\right.$ assay) was done by a standard technique. The binding of sera to native DNA was studied by the Millipore filter radioimmunoassay (Millipore Corp., Bedford, Mass.) using human KB cell line [ $\left.{ }^{3} \mathrm{H}\right] \mathrm{DNA}$ (Electro-Nucleonics, Inc., Fairfield, N. J.) (14).

Adsorption of anti-DNA antibody on DNA-cellulose columns. Calf thymus DNA-cellulose (Worthington Biochemical Corp., Freehold, N. J.) was suspended in buffer (0.01 M Tris- $\mathrm{HCl}, 0.001 \mathrm{M}$ EDTA, pH 7.4), and packed in columns (K9/15 columns, Pharmacia Fine Chemicals, Uppsala, Sweden). For each $2 \mathrm{~g}$ of DNA-cellulose (containing $18 \mathrm{mg} \mathrm{DNA}$ ), $10 \mathrm{ml}$ of serum was allowed to pass through the column at $4^{\circ} \mathrm{C}$ at a rate of 2 drops $/ \mathrm{min}$. The effluents were passed again through the DNA-cellulose columns to insure complete removal of the anti-DNA antibody. Sera treated in this manner did not contain any detectable anti-DNA antibody ( $0 \%$ binding) when tested by radioimmunoassay (14). Cellulose columns to which no DNA was coupled were incapable of depleting anti-DNA antibody.

Treatment of DNA with immobilized DNAse. 6 or $60 \mathrm{U}$ of DNAse-Sepharose conjugate (immobilized deoxyribonucleuse, Worthington Biochemical Corp.), suspended in $1.0 \mathrm{ml}$, was incubated with $10 \mu \mathrm{g}\left[{ }^{3} \mathrm{H}\right] \mathrm{DNA}$ for $60 \mathrm{~min}$ at $37^{\circ} \mathrm{C}$. The tubes were centrifuged at $720 \mathrm{~g}$ for $20 \mathrm{~min}$, and $0.5 \mathrm{ml}$ of the supernate was then dialyzed overnight against Tris-buffer saline. The DNA treated in this manner failed to bind to serum containing DNA antibodies. Thus, in a typical experiment, serum from an active lupus patient with $67 \%$ binding capacity $(17,279$ counts $/ \mathrm{min})$ to the undigested $\left[{ }^{3} \mathrm{H}\right] \mathrm{DNA}$ failed to bind to the DNAse-treated $\left[{ }^{3} \mathrm{H}\right] \mathrm{DNA}$ ( $<1 \%$ binding). $6 \mathrm{U}$ of DNAse-Sepharose conjugate was as efficient as $60 \mathrm{U}$. Therefore, in all the experiments reported in this paper $6 \mathrm{U}$ of immobilized DNAse was used for the digestion of $1.0 \mathrm{ml}$ of serum.

Suppression of anti-DNA binding to $\left[{ }^{3} \mathrm{H}\right] \mathrm{DNA}$ by blocking sera or immunoglobulin fragments and testing of precipitate formation by Clq-binding assay. All sera to be tested for the presence of anti-anti-DNA antibody (antiidiotypic or blocking antibodies) were depleted of anti-DNA antibody by passage twice through DNA-cellulose columns and then treated with $6 \mathrm{U}$ of DNAse-Sepharose to digest DNA. In preliminary experiments, lupus sera with $90 \%$ DNA-binding capacity or with $10 \mu \mathrm{g} \mathrm{DNA} / \mathrm{ml}$ could be completely depleted by this treatment. None of the blocking sera used in these experiments had DNA-binding capacity $>90 \%$ or DNA $>10 \mu \mathrm{g} / \mathrm{ml}$. Adequacy of depletion was confirmed by the failure to detect anti-DNA antibody by radioimmunoassay (14) and of DNA by chromatography (15). The anti-DNA depleted and DNAsetreated sera (blocking sera) were assayed for their capacity to inhibit the binding of $\left[{ }^{3} \mathrm{H}\right] \mathrm{DNA}$ to sera from active lupus patients (target sera). For the blocking assay $100 \mu \mathrm{l}$ containing $1 \mathrm{nmol}$ of the blocking material IgG or its various fragments was incubated with $100 \mu \mathrm{l}$ of a target serum (containing $1 \mathrm{nmol} \mathrm{IgG}$ ) at $37^{\circ} \mathrm{C}$ for $1 \mathrm{~h}$ and then for $16 \mathrm{~h}$ at $4^{\circ} \mathrm{C}$. The mixtures were centrifuged at $1,000 \mathrm{~g}$ for $30 \mathrm{~min} ; 100 \mu \mathrm{l}$ of the supernate was collected and tested in the standard DNA-binding assay (14). The remaining $100 \mu \mathrm{l}$, designated the precipitate fraction, was tested in a conventional Clq binding assay (16).

The percent suppression of DNA binding was calculated from the formula:

DNA binding of mixtures of target

$$
\left(1-\frac{\text { and blocking sera }}{\text { DNA binding of target sera alone }}\right) \times 100 \text {. }
$$

Depletion of various Ig classes. Depletion of serum IgG, IgM, or IgA was performed by standard techniques as described earlier (17). Adequacy of depletion was confirmed by immunoelectrophoresis and by immunodiffusion.

Preparation of $\operatorname{IgG}, F(a b)_{2}{ }_{2}$, and $F c$ fragments. IgG proteins were isolated from serum by affinity chromatography on Protein A-Sepharose 4B (Pharmacia Fine Chemicals, Uppsala, Sweden). $\mathrm{F}\left(\mathrm{ab} \mathrm{b}^{\prime}\right)_{2}$ fragments produced by pepsin digestion of IgG proteins were separated from Fc-containing materials by passing over a column of Protein A-Sepharose 4B (18). Fab and $\mathrm{Fc}$ fragments, which were produced by papain digestion of IgG proteins, were separated also by Protein A-Sepharose $4 \mathrm{~B}$ chromatography (18). These IgG fragments were separately passed through a column of Sephadex G-150 to ensure the removal of undigested IgG proteins. IgG and its enzymatic cleavage fragments thus prepared were immunologically pure and distinct when examined by immunoelectrophoresis.

Preparation of $F\left(a b^{\prime}\right)_{2}$ fragments from active lupus sera. To ensure that the blocking activity of the antiidiotypic antibody is directed towards the binding sites of anti-DNA antibody, we prepared $F\left(a b^{\prime}\right)_{2}$ fragments from IgG isolated from active lupus sera. The isolation of IgG proteins on Protein A-Sepharose $4 \mathrm{~B}$ and the preparation of $\mathrm{F}\left(\mathrm{ab}^{\prime}\right)_{2}$ fragments by pepsin digestion were as described above. 
Preparation of normal gammaglobulin immunoadsorbents. To ensure the specificity of the antiidiotypic antibody, we attempted to deplete its blocking activity by passing it through normal gammaglobulin immunoadsorbent columns. Gammaglobulins were isolated from five different normal sera by $33 \%$ ammonium sulfate precipitation. The precipitate was washed, dialyzed, redissolved, and covalently coupled to $\mathrm{CNBr}$ activated Sepharose $4 \mathrm{~B}$ according to the method described by March et al. (19). Such affinity chromatography media were denoted as gammaglobulin immunoadsorbents. Aliquots of one antiidiotypic serum - prepared from inactive lupus serum as described above-were allowed to pass through the five different immunoadsorbents. The blocking activity of the antiidiotypic serum was tested before and after its passage through the various immunoadsorbents.

Hemagglutination assay. To test for specificity of the autoantiidiotypic antibody, serum from a normal donor who had recently been boosted with tetanus toxoid was used as the target serum. Antitetanus antibody was assayed by the standard passive hemagglutination assay using chromium chloride to coat sheep erythrocytes with tetanus toxoid (20).

Statistical analysis. The paired $t$ test was used to compare suppression of target sera in the presence or absence of blocking sera. For comparison of percent suppression with Clq binding, the Spearman rank correlation coefficient was calculated (21).

\section{RESULTS}

Blocking of anti-DNA binding. Autologous sera from lupus patients with inactive disease $(n=19)$ were found to suppress the binding of $\left[{ }^{3} \mathrm{H}\right] \mathrm{DNA}$ to the target lupus sera $(P<0.01)$ (Fig. 1, Table I). Blocking sera from active unrelated $(n=9)$, from active autologous $(n=19)$, or from inactive unrelated $(n=9)$ lupus patients were not capable of suppression. Human serum albumin at a similar protein concentration and processed similarly to the various blocking sera was also incapable of suppression (Fig. 1). The mean suppression value of the 19 various normal sera tested, when pooled together, was not significantly different from the percent DNA binding of the target lupus sera

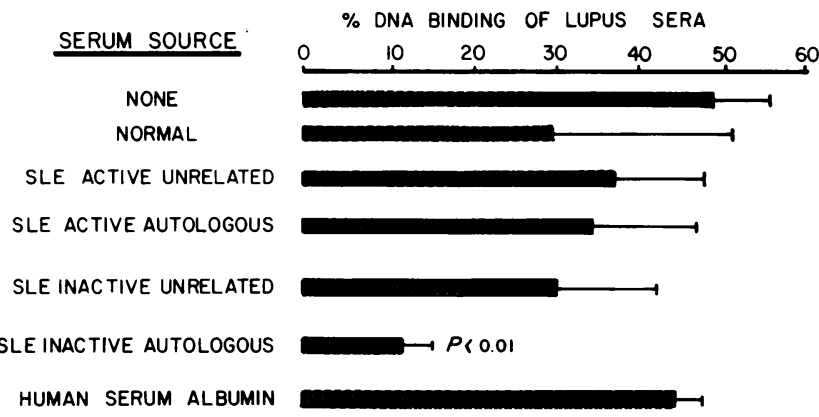

DNA adsorbed and DNASE treated

Figure 1 Suppression of anti-DNA binding to $\left[{ }^{3} \mathrm{H}\right]$ DNA by various sera. Results are the means \pm SD. 19 sera were tested for each of the normals, SLE active autologous, and SLE inactive autologous groups. Nine sera were tested for each of SLE active unrelated and SLE inactive unrelated groups. by themselves $(P=0.2)$ (Fig. 1, Table I). However, normal sera from donors who had contact with lupus patients and lupus blood components had significant suppressive activity on the target active lupus sera $(P$ $<0.02$ ) (Tables I and II). Sera from normal donors who had no contact with lupus material did not suppress $(P>0.5)$ (Table II).

Clq binding correlated with suppression of DNA binding. Precipitate fractions obtained from incubating $\mathrm{F}\left(\mathrm{ab}^{\prime}\right)_{2}$ fragments with the corresponding autologous target sera were tested for their ability to bind ${ }^{125}$ IClq by radioimmunoassay. The upper limits of the $95 \%$ confidence intervals for individual values of fragments from active lupus sera are shown with dotted lines parallel to each axis (25\% for suppression, $8 \%$ for Clq binding) (Fig. 2). Low Clq binding values (3-7\%) occurred with sera and fragments from active lupus patients; higher Clq binding values $(8-34 \%)$ occurred with those from patients with inactive lupus (Fig. 2). When samples from patients with active and inactive disease were considered together, percent suppression correlated significantly with Clq binding (Spearman's rho $=0.92, P<0.01$ ).

Effects of immunoglobulin depletion of the blocking sera. In the five experiments performed on five different sera, depletion of IgG eliminated the suppressive capacity of the autologous inactive lupus serum (Fig. 3). Depletion of IgM or of IgA failed to do so ( $P$ $<0.01)$.

Failure of depletion of the blocking activity by adsorption on normal human gammaglobulin. To avoid artefacts upon IgG depletion of blocking sera by immunoadsorbents, it is shown in Table III that normal gammaglobulin immunoadsorbents from five different donors failed to deplete the blocking activity of the lupus serum.

Effects of IgG fragments on DNA binding. In the nine sera that were processed and tested, $F\left(a b^{\prime}\right)_{2}$ fragments and not $\mathrm{F}_{\mathrm{c}}$ fragments of the inactive lupus sera were capable of suppressing the binding of anti-DNA antibody to $\left[{ }^{3} \mathrm{H}\right] \mathrm{DNA}(P<0.001)$ (Fig. 4). Fab fragments $(P<0.02)$, whole serum $(P<0.01)$, and globulin fractions $(P<0.01)$ were also inhibitory.

Effects of the blocking IgG on binding of $F\left(a b^{\prime}\right)_{2}$ fragments of the active lupus IgG to $\left[{ }^{3} \mathrm{H}\right] D N A$.. To ensure that the blocking activity of the inactive autologous IgG is directed towards the binding sites of the anti-DNA antibody, we have prepared $F\left(a b^{\prime}\right)_{2}$ fragments from IgG of five different active lupus sera. It could be seen from Table IV that the blocking IgG inhibited the binding of the $\mathrm{F}\left(\mathrm{ab}^{\prime}\right)_{2}$ fragments to $\left[{ }^{3} \mathrm{H}\right]$ DNA. Fc fragments prepared from the same active lupus sera failed to bind to $\left[{ }^{3} \mathrm{H}\right] \mathrm{DNA}$ in the absence or presence of the blocking IgG (not shown in Table IV).

Effect of IgG fragments on tetanus toxoid binding. Whole serum, globulin fraction, or the various IgG frag- 
TABLE I

Serum DNA Binding before and after Treatment with the Blocking Serum

\begin{tabular}{|c|c|c|c|c|}
\hline \multirow[b]{3}{*}{ Patient } & \multirow[b]{3}{*}{ Predominant clinical features } & \multicolumn{3}{|c|}{ DNA binding of lupus sera } \\
\hline & & \multirow[b]{2}{*}{$\begin{array}{c}\text { Before } \\
\text { incubation }\end{array}$} & \multicolumn{2}{|c|}{ After incubation with sera } \\
\hline & & & $\begin{array}{l}\text { Autologous } \\
\text { inactive }\end{array}$ & Normal \\
\hline & & & $\%$ & \\
\hline 1 & Nephritis, cytopenia, CNS & 58 & 10 & $23^{*}$ \\
\hline 2 & Nephritis & 46 & 8 & 39 \\
\hline 3 & Hemolytic anemia, cutaneous & 44 & 18 & 33 \\
\hline 4 & Thrombocytopenia, nephritis & 53 & 12 & 43 \\
\hline 5 & Serositis, cutaneous & 39 & 13 & 26 \\
\hline 6 & Arthritis, nephritis & 58 & 9 & $19^{*}$ \\
\hline 7 & Fatigue, arthritis & 42 & 14 & 27 \\
\hline 8 & Cutaneous vasculitis & 43 & 6 & 30 \\
\hline 9 & Serositis & 46 & 10 & $25^{*}$ \\
\hline 10 & CNS, nephritis & 52 & 14 & 39 \\
\hline 11 & Nephritis & 61 & 11 & 46 \\
\hline 12 & Fatigue, arthralgia & 45 & 12 & 29 \\
\hline 13 & Nephritis, arthralgia & 64 & 20 & $10^{*}$ \\
\hline 14 & Thrombocytopenia, arthralgia & 31 & 12 & 24 \\
\hline 15 & Cytopenia, nephritis & 39 & 20 & $18^{*}$ \\
\hline 16 & Serositis & 30 & 6 & 23 \\
\hline 17 & Nephritis, arthritis & 61 & 14 & 51 \\
\hline 18 & Nephritis, cutaneous & 35 & 10 & 25 \\
\hline 19 & Serositis, arthritis & 40 & 12 & 31 \\
\hline Mean & - & 47 & 12 & 30 \\
\hline
\end{tabular}

* Sera from donors who had contact with lupus material.

ments of the same nine inactive lupus sera tested above for their anti-anti-DNA antibody activity did not inhibit the antitetanus antibody binding to tetanus toxoid as tested by a hemagglutination technique (Fig. 5).

\section{DISCUSSION}

The clonal selection theory has prevailed for many years and has suggested that the immune system is made up of lymphocyte clones capable of binding to a multitude of antigens (22). During ontogeny, selfreactive (forbidden) clones were thought to be destroyed and the surviving clones were believed to be directed mainly against nonself antigens (22). However, a number of recent important findings have revealed new complexities. Self-reactive clones could be detected in normal individuals $(23,24)$. The discovery

TABLE II

Suppression of Anti-DNA Binding to $\left[{ }^{3} H\right] D N A$ by Normal Sera

\begin{tabular}{|c|c|c|c|c|c|c|}
\hline & & & Anti-1 & nding of ta & pus sera§ & \\
\hline & 1 sera* & & & & & \\
\hline $\begin{array}{l}\text { Number } \\
\text { tested }\end{array}$ & $\begin{array}{l}\text { DNA antibody } \\
\text { binding }\end{array}$ & $\begin{array}{l}\text { with lupus } \\
\text { material }\end{array}$ & $\begin{array}{c}\text { Before } \\
\text { blocking }\end{array}$ & $\begin{array}{c}\text { After } \\
\text { blocking }\end{array}$ & Suppression & $P$ \\
\hline & $\%$ & & & & $\%$ & \\
\hline 14 & $3.4 \pm 2.9$ & No & $44 \pm 13$ & $33 \pm 12$ & 25 & $>0.5$ \\
\hline 5 & $4.1 \pm 2.3$ & Yes & $53 \pm 19$ & $19 \pm 11$ & 64 & $<0.02$ \\
\hline
\end{tabular}

* Normal healthy volunteers with negative personal or family history of lupus.

$\ddagger$ Contact with lupus patients and lupus blood components for 0.5-16 yr.

$\S$ Five different lupus sera were used as targets for suppression by the normal sera in all the experiments. Each blocking normal serum that had been adsorbed on DNA-cellulose columns and DNAse-treated was tested for its suppressive capacity of each of the target lupus sera. 


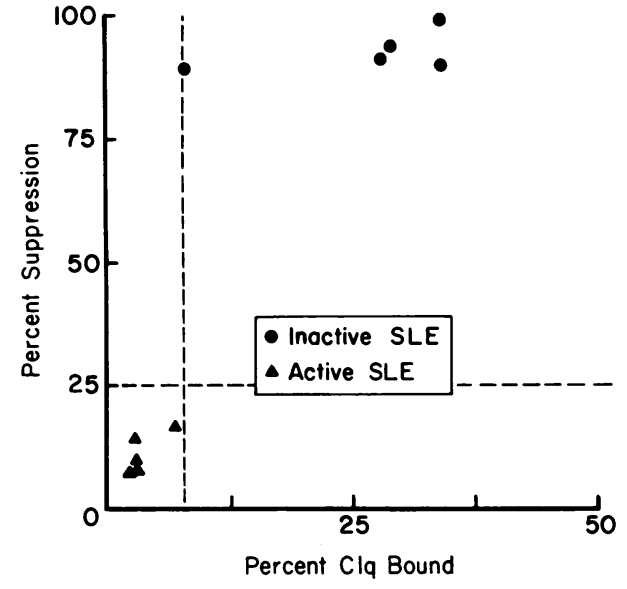

Figure 2 Clq binding was measured on a precipitate fraction formed by the interaction of lupus $\mathbf{F}\left(\mathrm{ab}^{\prime}\right)_{2}$ with autologous target serum (see Methods). Percent suppression of DNA binding was determined on the same assay tubes. The upper limit of the $95 \%$ confidence interval, for the samples from patients with active disease only, are shown as dotted lines parallel to the corresponding axis. There was a significant correlation (Spearman's rho $=0.92, P<0.01$ ) between Clq binding and the degree of suppression of DNA binding. $F\left(\mathrm{ab}^{\prime}\right)_{2}$ fragments from sera of active patients clustered in the lower left quadrant and were easily distinguished from those with inactive disease.

of positive and negative interactions between $\mathrm{T}$ and $\mathrm{B}$ lymphocytes (7) and the possible involvement of idiotypes in clonal interactions (4) indicate that the immune system can recognize self and is regulated by a complex idiotypic network (1-5). Idiotypes and autoantiidiotypes coexist in the repertoire of a single individual; autoantiidiotypes can be induced or occur spontaneously during the immune response $(4,25-27)$. These antiidiotypic antibodies can exert either positive or negative influences on antibody biosynthesis or on effector cell function $(10,27)$.

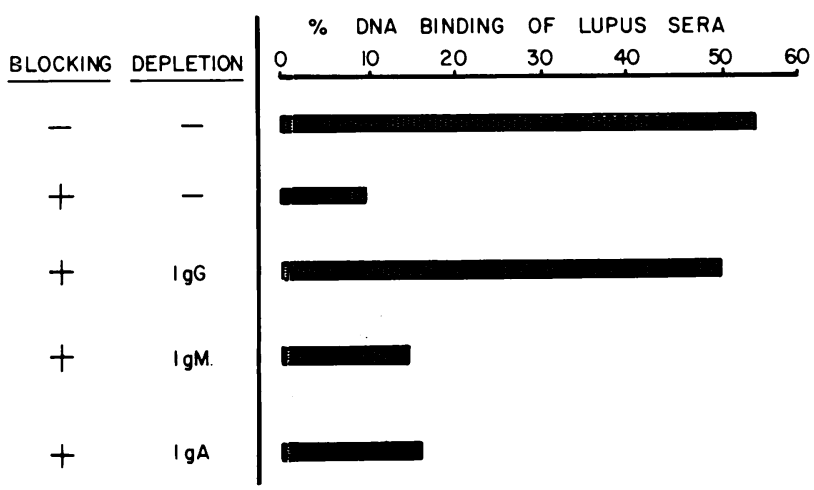

FIGURE 3 Suppression of anti-DNA binding to $\left[{ }^{3} \mathrm{H}\right]$ DNA by autologous inactive lupus sera, and effects of depletion of various immunoglobulin classes. Five different sera were processed and tested. Results are the means of all the experiments. The standard deviation did not exceed $7 \%$ of the mean.
TABLE III

Effects on Blocking Activity of Antiidiotypic Serum upon Its Adsorption by Normal Human Gammaglobulin

\begin{tabular}{ccc}
\hline \multirow{2}{*}{$\begin{array}{c}\text { Gammaglobulin } \\
\text { immunoadsorbent } \\
\text { from normal donors* }\end{array}$} & \multicolumn{2}{c}{$\begin{array}{c}\text { Suppression of the target lupus serum } \\
\text { upon incubation with blocking serum } \S\end{array}$} \\
\cline { 2 - 3 } & $\begin{array}{c}\text { Not adsorbed by } \\
\text { normal gammaglobulin }\end{array}$ & $\begin{array}{c}\text { Adsorbed by normal } \\
\text { gammaglobulin }\end{array}$ \\
\hline & & \\
1 & 83 & \\
2 & 83 & 80 \\
3 & 83 & 82 \\
4 & 83 & 79 \\
5 & 83 & 85 \\
\end{tabular}

* Five different normal donors' gammaglobulin were linked to CnBr-activated Sepharose 4B. See Methods for details.

$\$$ Target serum was from active lupus patient with $53 \%$ binding to $\left[{ }^{3} \mathrm{H}\right]$ DNA.

$\S$ Blocking serum was obtained from same donor of the target serum during disease inactivity. The blocking serum was first depleted of anti-DNA antibody and of DNA. Part of the depleted blocking serum was adsorbed onto normal gammaglobulin solid immunoadsorbents. See methods section for the calculation of percent suppression of the blocking activity.

In this report we have examined the modulation of autoantibody activity by means of antiidiotypic antibodies. We have demonstrated that binding of antiDNA antibody to DNA could be blocked by $\mathrm{F}\left(\mathrm{ab}^{\prime}\right)_{2}$ and Fab fragments of IgG obtained from autologous sera of inactive lupus patients (Fig. 4). Blocking activity was probably due to occupancy of the combining site, since $\mathrm{Fc}_{\mathrm{c}}$ fragments of the same IgG had no blocking activity. We have not ruled out, however, the possi-

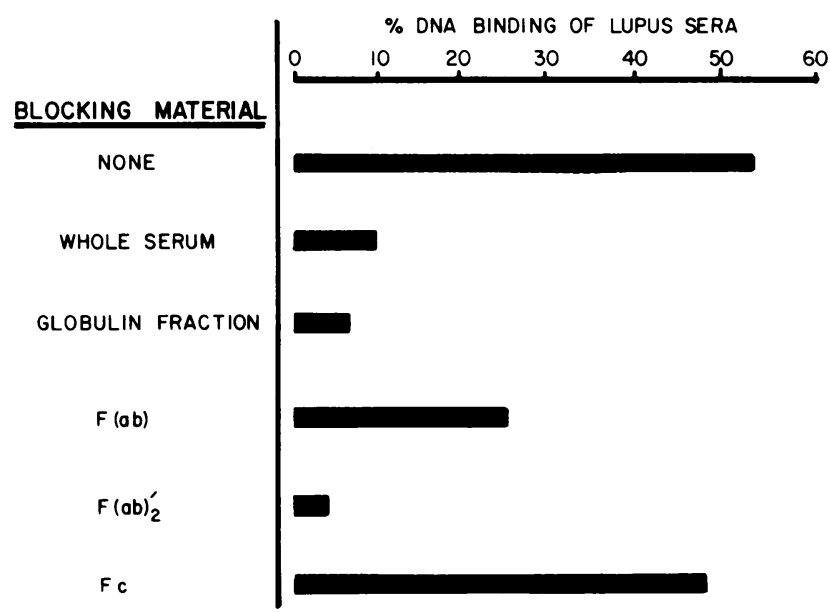

FIGURE 4 Suppression of anti-DNA binding to $\left[{ }^{3} \mathrm{H}\right] \mathrm{DNA}$ by various immunoglobulin fragments of the inactive lupus serum. Nine different sera were processed and tested. Results shown are the means of all experiments. The standard deviation did not exceed $9.3 \%$ of the mean. 
TABLE IV

Blocking of the Binding of Active Lupus $F\left(a b^{\prime}\right)_{2}$ Fragments to $\left[{ }^{3} \mathrm{H}\right] D N A$ by Autologous IgG

\begin{tabular}{|c|c|c|c|}
\hline \multirow[b]{2}{*}{ Experiment* } & \multicolumn{2}{|c|}{$\begin{array}{l}{\left[{ }^{3} \mathrm{H}\right] \text { DNA binding to }} \\
\mathrm{F}\left(\mathrm{ab}^{\prime}\right)_{2} \text { fragments } \downarrow\end{array}$} & \multirow[b]{2}{*}{ Suppression" } \\
\hline & $\begin{array}{l}\text { In absence of } \\
\text { blocking IgG }\end{array}$ & $\begin{array}{l}\text { In presence of } \\
\text { blocking IgG } \$\end{array}$ & \\
\hline & \multicolumn{2}{|c|}{$\%$} & $\%$ \\
\hline 1 & 63 & 19 & 70 \\
\hline 2 & 41 & 8 & 80 \\
\hline 3 & 53 & 9 & 83 \\
\hline 4 & 34 & 14 & 59 \\
\hline 5 & 39 & 12 & 69 \\
\hline
\end{tabular}

* Five different active lupus sera were tested.

$\$ \mathrm{~F}\left(\mathrm{ab}^{\prime}\right)_{2}$ fragments prepared from IgG fractions of the active lupus sera.

$\S$ Blocking IgG is obtained from autologous inactive lupus serum that was depleted of anti-DNA antibody and of DNA.

"Calculated from the formula

$$
\left(1-\frac{\text { binding in presence of blocking } \operatorname{IgG}}{\text { binding in absence of blocking } \operatorname{IgG}}\right) \times 100 \text {. }
$$

bility that blocking is due to anti-light chain activity, or due to DNA fragments present in the inactive lupus serum. We have ruled out the possibility that the blocking factor is due to rheumatoid factor activity, since the former was capable of blocking the binding of $F\left(a b^{\prime}\right)_{2}$ fragments of the active lupus sera (Table IV). It is unlikely that the suppressed activity of the anti-DNA antibody was due to its aggregation

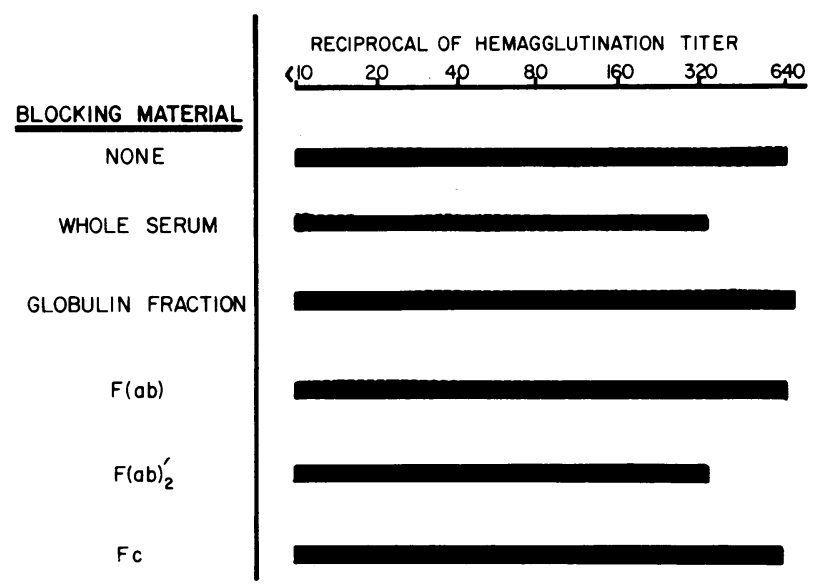

FIgURE 5 Suppression of tetanus toxoid binding to antitetanus antibody by various immunoglobulin fragments of the inactive lupus serum. Nine different sera were processed and tested. Results are the means of all the experiments. The standard deviation did not exceed one tube dilution. upon overnight incubation, since sera incubated without the blocking material and processed in an identical manner had similar DNA-binding activity to that before incubation. The anti-anti-DNA activity could not be detected in active lupus sera (Fig. 1), could not be adsorbed by normal human gammaglobulin (Table III), could not block an unrelated antigen-antibody reaction (Fig. 5), and was directed towards $F\left(a b^{\prime}\right)_{2}$ fragments of the anti-DNA antibody (Table IV). Sera from normal donors who had contact with lupus patients and lupus blood components had anti-anti-DNA activity, indicating the probable presence of cross-reacting antiidiotypic antibodies in their sera (Table I). Specificity of the blocking activity of the normal sera for the Fab portion of IgG was not tested. Inhibition of anti-DNA binding by normal human serum has been observed previously (28).

The factors responsible for the production of the cross-reacting (nonautologous) antiidiotypic antibodies in the normal donors who had contact with lupus materials are unknown. This could reflect a regulatory mechanism in a normal protective immune response. Lymphocytotoxic antibodies and antinuclear antibodies (29), but not Sm antibodies (30), have been found in families of lupus patients. Laboratory personnel in contact with lupus materials have increased levels of lymphocytotoxic antibodies (31), but not anti-double-stranded DNA antibodies (Table I). Failure to detect specific serum antibodies (antiDNA, anti-Sm) in family members and normals in contact with lupus materials could be attributed to an efficient regulation by an autoantiidiotypic antibody and/ or the lack of a particular immune response gene for the development of the disease (32).

The formation of immune precipitates upon binding of anti-DNA antibody to the antiidiotypic antibody was tested by the Clq binding assay. $\mathrm{F}\left(\mathrm{ab}^{\prime}\right)_{2}$ fragments from IgG of four patients with inactive disease clearly exceeded the calculated range for fragments from patients with active lupus (Fig. 2). We presume that the radioiodinated Clq is binding an immune precipitate, although we have no direct proof that this is so. A solidphase Clq binding assay or Raji cell assay would permit direct evidence, since a radioiodinated anti-IgG antibody is used to detect an immune complex.

The interplay and the complexity of the various regulatory mechanisms in autoimmunity have been discussed $(4,5,33)$. In active SLE, suppressor T cells are deficient or dysfunctional $(8,34,35)$. In inactive SLE, suppressor $\mathrm{T}$ cells are capable of inhibiting immunoglobulin and anti-DNA antibody secretion (34). The same suppressor cells collected from inactive SLE patients are, however, incapable of affecting the number of DNA-binding autoreactive clones (34). Our pre- 
liminary results indicate that the autoantiidiotypic antibody, in the presence of guinea pig complement, is capable of killing DNA-binding B cells (36). Based on these findings, we propose that there are two levels of regulation of anti-DNA antibody in SLE: one modulated by suppressor cells, and a second modulated by an antianti-DNA antibody. The factors responsible for the activation of suppressor cells and for autoantiidiotypic antibody production in the inactive SLE state are unknown. Clearer understanding of all the regulatory elements awaits the completion of critical and reproducible studies dealing with the role of exogenous infectious agents, genetic and hormonal factors that might participate in the pathogenesis of SLE.

\section{ACKNOWLEDGMENTS}

We thank Deborah Marino, Terrill K. Smith, and Laura Janecek for their excellent technical assitance; Anne Knight and Juanita Stika for their secretarial help; and Dr. Daniel J. Stechschulte, Dr. John D. Martinez, Judy Medved, and Kay Appleberry for their cooperation and participation in the care of some of the patients.

The work was supported by National Institutes of Health grants AI-15360 and AI-15880, by the Veterans Administration, by the Kansas Chapter of the Arthritis Foundation, by the Oklahoma Chapter of the Lupus Foundation and by the Upjohn Company.

\section{REFERENCES}

1. Jerne, N. K. 1974. Towards a network theory of the immune system. Ann. Immunol. (Inst. Pasteur). 125C: 373-389.

2. Wigzell, H., and H. Binz. 1979. Anti-idiotype antibodies. Induction of specific transplantation tolerance in adult animals. Transplant. Proc. 11: 914-918.

3. Cosenza, H., and H. Kohler. 1972. Specific suppression of the antibody response by antibodies to receptors. Proc. Natl. Acad. Sci. U. S. A. 69: 2701-2705.

4. Urbain, J., C. Collignon, J. D. Franssen, B. Mariame, O. Leo, G. U. Vansanten, P. V. Walle, M. Wikler, and C. Wuilmart. 1979. Idiotypic networks and self-recognition in the immune system. Ann. Immunol. (Inst. Pasteur). 130C: 281-291.

5. Talal, N. 1978. Autoimmunity and the immunologic network. Arthritis Rheum. 21: 853-861.

6. Adams, D. D., and J. G. Knight. 1980. H gene theory of inherited autoimmune disease. Lancet. I: 396-398.

7. Allison, A. C. 1974. The roles of T and B lymphocytes in self tolerance and autoimmunity. Contemp. Top. Immunobiol. 3: 227-239.

8. Abdou, N. I., A. Sagawa, E. Pascual, J. Hebert, and S. Sadeghee. 1976. Suppressor T cell abnormality in idiopathic systemic lupus erythematosus. Clin. Immunol. Immunopathol. 6: 192-199.

9. Raveche, E. S., and A. D. Steinberg. 1979. Lymphocytes and lymphocyte functions in systemic lupus erythematosus. Semin. Hematol. 16: 344-370.

10. Eichmann, K., and K. Rajewsky. 1975. Induction of T and $\mathrm{B}$ cell immunity by anti-idiotypic antibody. Eur. J. Immunol. 5: 661-666.
11. Weinberger, J. Z., R. N. Germain, S. I. Ju, M. I. Greenbe, B. Benacerraf, and M. E. Dorf. 1979. Hapten-specific Tcell responses to 4-hydroxy-3-nitrophenyl acetyl. II. Demonstration of idiotypic determinants on suppressor $\mathrm{T}$ cells. J. Exp. Med. 150: 761-776.

12. Bona, C., and W. E. Paul. 1979. Cellular basis of regulation of expression of idiotype. I. T-suppressor cells specific for MOPC 460 idiotype regulate the expression of cells secreting anti-TNP antibodies bearing 460 idiotype. J. Exp. Med. 149: 592-600.

13. Cohen, A. S., W. E. Reynolds, E. C. Franklin, J. P. Kulka M. W. Ropes, L. E. Schulman, and S. L. Wallace. 1971. Preliminary criteria for the classification of systemic lupus erythematosus. Bull. Rheum. Dis. 21: 643-648.

14. Ginsberg, B., and H. Keiser. 1973. A millipore filter assay for antibodies to native DNA in sera of patients with systemic lupus erythematosus. Arthritis Rheum. 16: 199-207.

15. Locker, J. D., M. E. Medof, R. M. Bennett, and S. Sukhupunyaraksa. 1977. Characterization of DNA used to assay sera for anti-DNA antibodies, determination of the specificities of anti-DNA antibodies in SLE and nonSLE rheumatic disease states. J. Immunol. 118: 694-701.

16. Zubler, R. H., U. Nydegger, L. H. Perrin, K. Fehr, J. McCormick, P. H. Lambert, and P. A. Miescher. 1976. Circulating and intraarticular immune complexes in patients with rheumatoid arthritis. J. Clin. Invest. 57: 1308-1319.

17. Sagawa, A., and N. I. Abdou. 1979. Suppressor-cell antibody in systemic lupus erythematosus. Possible mechanism for suppressor-cell dysfunction. J. Clin. Invest. 63: 536-539.

18. Garvey, J. S., N. E. Cremer, and D. H. Sussdorf. 1977. Subunits of IgG, Fab, $\mathrm{F}\left(\mathrm{ab}^{\prime}\right)_{2}$ and $\mathrm{Fc}$ fragments. In Methods in Immunology. J. S. Garvey, N. E. Cremer, and D. H. Sussdorf, editors. W. A. Benjamin, Inc., Reading, Mass. 3rd edition. 256-266.

19. March, S. C., I. Parikh, and P. Cuatrecasas. 1974. A simplified method for cyanogen bromide activation of agarose for affinity chromatography. Anal. Biochem. 60: 149-152.

20. Sasaki, T., S. Ishida, S. Onodera, T. Saito, T. Furuyama, and K. Yoshinaga. 1978. Passive hemagglutination and hemolysis tests for the detection of anti-DNA antibody. J. Immunol. Methods. 22: 327-337.

21. Siegel, S. 1956. Nonparametric Statistics for the Behavioral Sciences. McGraw-Hill Book Co., Inc., New York 202-213.

22. Burnet, M. 1959. In The Clonal Selection Theory of Acquired Immunity. Cambridge University Press, New York. 33-36.

23. Bankhurst, A. D., and R. C. Williams. 1975. Identification of DNA-binding lymphocytes in patients with systemic lupus erythematosus. J. Clin. Invest. 56: 1378-1385.

24. Hebert, J., S. Sadeghee, H. R. Schumacher, B. Zweiman, C. Zmijewski, and N. I. Abdou. 1976. Null cells in peripheral blood of normals and systemic lupus erythematosus. Clin. Immunol. Immunopathol. 6: 347-350.

25. Brown, J. C., and L. S. Rodkey. 1979. Autoregulation of an antibody response via network-induced auto-anti-idiotype. J. Exp. Med. 150: 67-85.

26. Schrater, A. F., E. A. Goidl, G. J. Thorbecke, and G. W. Siskind. 1979. Production of auto-anti-idiotypic antibody during the normal immune response to TNP-Ficoll. $J$. Exp. Med. 150: 138-153.

27. Zubler, R. H., B. Benacerraf, and R. N. Germain. 1980 
Feedback suppression of the immune response in vitro. II. $\mathrm{IgV}_{\mathrm{H}}$-restricted antibody-dependent suppression. $J$. Exp. Med. 151: 681-694.

28. Halsey, J. F., W. A. Woolery, S. Oleinick, M. B. Kahaleh, and E. C. LeRoy. 1979. DNA binding activity of serum from patients with systemic lupus erythematosus. Clin. Exp. Immunol. 35: 356-363.

29. DeHoratious, R. J. 1980. Lymphocytotoxic antibodies. Progr. Clin. Immunol. 4: 151-174.

30. Do!l, N. J., M. R. Wilson, and J. E. Salvaggio. 1980. Prevalence of Sm antibody in family members of Sm positive patients with systemic lupus erythematosus. $J$. Rheumatol. 7: 334-338.

31. DeHoratious, R. J., R. Rubin, R. P. Messner, and R. I. Carr. 1979. Lymphocytotoxic antibodies in laboratory personnel exposed to SLE sera. Lancet II: 1141-1142.

32. Miller, K. B., and R. S. Schwartz. 1979. Familial abnor- malities of suppressor cell function in systemic lupus erythematosus. N. Engl. J. Med. 301: 803-809.

33. Bankhurst, A. D., and R. C. Williams. 1976. Cellular origin of auto-antibody-A perplexing question. Am. J. Med. 61: 303-307.

34. Sagawa, A., and N. I. Abdou. 1978. Suppressor cell dysfunction in systemic lupus erythematosus. Cells involved and in vitro correction. J. Clin. Invest. 62: 789-796.

35. Sakane, T., A. D. Steinberg, and I. Green. 1978. Studies of immune functions of patients with systemic lupus erythematosus. Dysfunction of suppressor T cell activity related to impaired generation of, rather than response, to suppressor cells. Arthritis Rheum. 21: 657-664.

36. Abdou, N. I., D. Marino, and H. Wall. 1980. The network theory in autoimmunity: modulation of DNA-binding cells by anti-idiotypic antibody present in inactive SLE sera. Arthritis Rheum. 23: 646. (Abstr.) 